\title{
EFFECTS OF N-3 FATTY ACID ENRICHMENT ON THE QUALITY CHARACTERISTICS OF A SPECIAL HUNGARIAN COLD CUT (PÁRIZSI)
}

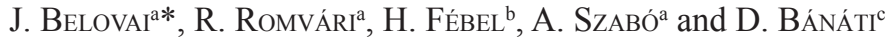 \\ ${ }^{a}$ Kaposvár University Faculty of Animal Science, H-7400 Kaposvár, Guba Sándor u. 40. Hungary \\ ${ }^{\mathrm{b}}$ Research Institute of Animal Breeding and Nutrition, H-2053, Herceghalom, Gesztenyés u. 1. Hungary \\ ${ }^{\mathrm{c}}$ International Life Sciences Institute - ILSI Europe a.i.s.b.l., \\ Avenue E. Mounier 83, Box 6 B-1200 Bruxelles. Belgium
}

(Received: 1 October 2012; accepted: 4 February 2013)

\begin{abstract}
The n-3 fatty acids advantageously affect human health. Thus, partial substitution of pig backfat with soybean- or flaxseed oils in "Párizsi" (lyoner), with the aim to increase its n-3 fatty acid (FA) content, resulted improved FA profile (n-6/n-3 ratio). Relatively high ( $9 \%$ flaxseed oil) substitution decreased this ratio to the optimum ( $\sim 4)$. This modified FA profile was preserved during 32 storage days. Oil addition influenced fresh surface colour: lightness $\left(\mathrm{L}^{*}\right)$ increased, redness $\left(\mathrm{a}^{*}\right)$ decreased in parallel with the increasing oil addition, while only soybean oil increased yellowness $\left(b^{*}\right)$. Storage altered the colour slightly. The texture was not systematically altered by oil substitution, while during storage in a vapour permeable casing hardness increased. Considering organoleptic properties, soybean oil improved the extent of spiciness, while the general consumer acceptance was the most favourable (within complemented samples) by $3 \%$ flaxseed oil. Increasing vegetable oil levels intensified the taste of spice mixture.

Keywords: meat product, n-3 fatty acids, functional food, soybean oil, flaxseed oil
\end{abstract}

Clinical studies provided evidence on the protective effect of n-3 polyunsaturated fatty acids (PUFAs) against some common cancer types (breast-, colon cancer) (Rose \& ConNolly, 1999), rheumatoid arthritis and cardiovascular diseases (AlEXANDER, 1998). The n-3 fatty acids are indispensable in human nutrition, being significant structural components of the cellular membranes (Neuringer et al., 1986). In Western Europe and the United States the dietary ratio of $n-6 / n-3$ is between 15:1 and 20:1 nowadays, instead of 1:1 (Simopoulos \& CHILDS, 1990). Most vegetable oils (e.g. sunflower oils) are very rich in $n-6$ and generally poor in $\mathrm{n}-3$ fatty acids (Simopoulos, 2001). The optimal $\mathrm{n}-6 / \mathrm{n}-3$ ratio in foods rich in $\mathrm{n}-3$ PUFAs is less than 4 and the PUFA/saturated FA ratio is higher than 0.4 (Wood et al., 2004). Different dietary sources of n-3 fatty acids are known, such as fish, seafood, some oilseeds or their oils. The main vegetable sources of n-3 fatty acids are flaxseed, soybean and rapeseed (KAMAL-Eldin \& ANDERsson, 1997; Riemersam, 2001). Flaxseed is the most important source of $\alpha$-linolenic acid (ALA), containing ca. $350 \mathrm{~g}$ ALA/1000 g seed. Consumption of n-3 fatty acid enriched food products is a recommended way to meet the human essential FA demands. A potential drawback of the use of n-3 FAs is their expressed susceptibility towards lipid peroxidation (St. ANGeLo, 1999) and their apparent off-flavour induction (SCHEIDELER et al., 1997).

\footnotetext{
* To whom correspondence should be addressed.

Phone: +3682505800; fax: +3682320167; e-mail: belovai.judit@ke.hu
} 
The aim of this study was to enrich one of the most popular meat product in Hungary, a special cold cut (Párizsi), directly with different vegetable oil n-3 FAs in a graded, substitution manner, to reach a more favourable FA composition and to determine the consequent changes of product parameters (colour, rheology, organoleptic properties).

\section{Materials and methods}

\subsection{Preparation of "Párizsi"}

The frozen and ground pork (spare rib) and backfat were chopped into fine cubes and put into a cutter. After 10 min ice cubes, vegetable oils (commercially available flaxseed and soybean oils, Solio Ltd., Hungary), spice mix (ProFood Ltd., Hungary), and nitrite pickling salt were added (Table 1) to the dollop and the mixing was continued till the dollop reached a perfectly homogeneous consistence. The level of vegetable oils was chosen on the basis of a preliminary experiment and sample numbering was kept. The final temperature of the dollop was kept under $14{ }^{\circ} \mathrm{C}$ during cuttering. The dollop was filled manually into vapour-permeable casings (diameter $5 \mathrm{~cm}$, length $20 \mathrm{~cm}$ ) and was heated in a fume hood to $72^{\circ} \mathrm{C}$ core temperature in a Bastra 850 (Bastra, Arnsberg, Germany) cooking/smoking chamber for approximately $1.5 \mathrm{~h}$. Finally the samples ( $250 \mathrm{~g}$ Párizsi/sample) were chilled to $4{ }^{\circ} \mathrm{C}$ in a refrigerator. The fatty acid composition of the raw meat, backfat and vegetable oils was determined (Table 2).

Table 1. Ingredients of the samples with graded vegetable oil substitution of the pig backfat

\begin{tabular}{lcccccccl}
\hline $\begin{array}{l}\text { Sample } \\
\text { code }\end{array}$ & $\begin{array}{c}\text { Pork } \\
\text { meat }(\mathrm{g})\end{array}$ & $\begin{array}{c}\text { Backfat } \\
(\mathrm{g})\end{array}$ & $\begin{array}{c}\text { Ice } \\
(\mathrm{g})\end{array}$ & $\begin{array}{c}\text { Soybean } \\
\text { oil }(\mathrm{g})\end{array}$ & $\begin{array}{c}\text { Flaxseed } \\
\text { oil }(\mathrm{g})\end{array}$ & $\begin{array}{c}\text { Spice } \\
\text { mix }(\mathrm{g})\end{array}$ & $\begin{array}{c}\text { Nitrite pickling salt } \\
(\mathrm{g})\end{array}$ & Rate of enrichment \\
\hline 1 & 1350 & 1200 & 450 & 0 & 0 & 30 & 60 & standard \\
2 & 1350 & 1164 & 450 & 36 & - & 30 & 60 & $3 \%$ soya oil \\
3 & 1350 & 1128 & 450 & 72 & - & 30 & 60 & $6 \%$ soya oil \\
4 & 1350 & 1092 & 450 & 108 & - & 30 & 60 & $9 \%$ soya oil \\
9 & 1350 & 1164 & 450 & - & 36 & 30 & 60 & $3 \%$ flaxseed oil \\
10 & 1350 & 1128 & 450 & - & 72 & 30 & 60 & $6 \%$ flaxseed oil \\
11 & 1350 & 1092 & 450 & - & 108 & 30 & 60 & $9 \%$ flaxseed oil \\
\hline
\end{tabular}

\subsection{Fatty acid analysis}

Samples (300 mg) were extracted according to FoLCH and co-workers (1957). Solvents were ultrapure-grade (Sigma-Aldrich, Schnelldorf, Germany) and 0.01\% (w:v) butylated hydroxytoluene was used as antioxidant. Lipids were transmethylated with the acid-catalysed methanolic $\mathrm{H}_{2} \mathrm{SO}_{4}$ method of CHRISTIE and HAN (2010). Nonadecaenoic acid (C19:0, Fluka) was added to the samples as an internal standard.

Gas liquid chromatography was performed on a Shimadzu 2100 apparatus, equipped with a SP-2380 (Supelco, Bellefonte, USA) type capillary column $(30 \mathrm{~m} \times 0.25 \mathrm{~mm}$ internal diameter, $0.20 \mu \mathrm{m}$ film thickness) and flame ionisation detector. To identify individual FA, a standard (Mixture Me100, Larodan Fine Chemicals, Malmö, Sweden) was used. 
Table 2. Fatty acid composition of the raw materials

\begin{tabular}{lcccc}
\hline & Meat & Backfat & Soybean oil & Flaxseed oil \\
\cline { 2 - 5 } & \multicolumn{4}{c}{$(\mathrm{w} / \mathrm{w} \%)$} \\
\hline C14:0 & 1.52 & 1.55 & 0.08 & 0.05 \\
C16:0 & 27.87 & 26.74 & 9.03 & 5.78 \\
C16:1 n7 & 3.99 & 2.74 & 0.10 & 0.07 \\
C18:0 & 14.46 & 13.99 & 3.45 & 3.74 \\
C18:1 n9 & 36.29 & 34.27 & 16.11 & 12.90 \\
C18:2 n6 & 16.07 & 65.08 & 44.79 \\
C18:3 n3 & 10.60 & 1.09 & 5.14 & 31.85 \\
C20:1 n9 & 0.52 & 0.86 & 0.16 & 0.15 \\
C20:4 n6 & 0.89 & 0.35 & $\mathrm{nd}$ & $\mathrm{nd}$ \\
$\Sigma$ saturated & 1.77 & 42.28 & 12.55 & 9.57 \\
$\Sigma$ MUFA & 37.87 & 16.37 & 13.12 \\
$\Sigma$ PUFA & 43.85 & 19.41 & 70.46 & 76.90 \\
PUFA/saturated & 41.17 & 0.46 & 5.61 & 8.04 \\
$\Sigma$ n3 & 14.83 & 1.35 & 5.20 & 31.88 \\
$\Sigma$ n6 & 0.34 & 17.20 & 65.11 & 44.87 \\
n6/n3 & 0.91 & 12.74 & 12.52 & 1.41 \\
\hline
\end{tabular}

nd: not detected

\subsection{Texture analysis}

The texture profile analysis (TPA) was performed in a Zwick Z005 equipment (Zwick Roell GmbH, Ulm, Germany) and Warner Bratzler scissors. The hardness (Fmax, N) was applied to describe the texture of $15 \mathrm{~mm}$ diameter sample cones. The constant crosshead speed was $50 \mathrm{~mm} \mathrm{~min}^{-1}$ and the measurement was performed at room temperature 5 times/sample.

\subsection{Colour measurement}

The colour measurement of Párizsi surface was obtained using a tristimulus colorimeter (Minolta Chroma Meter CR-300, Minolta Corporation, Tokyo, Japan). The b* (yellowness), $\mathrm{a}^{*}$ (redness) and $\mathrm{L}^{*}$ (lightness) values were measured three times on the surface of the Párizsi at six different times in parallel with the chemical analysis. In each case the measurement was repeated 5 times/sample.

\subsection{Oxidation}

The acid value of the lipid contents of the sample was determined with the IUPAC (1987) method 2.201 and results were expressed as $\mathrm{mg} \mathrm{KOH} / \mathrm{g}$ fat, while peroxide value was determined according to the A.O.A.C. (1995) method and was expressed as meq $\mathrm{O}_{2} / \mathrm{kg}$ fat in 3 repetitions/sample. 


\subsection{Organoleptic analysis}

The organoleptic analysis was performed by 10 skilled evaluators with only fresh samples $\left(1^{\text {st }}\right.$ day), at the Central Food Research Institute (Budapest, Hungary). Product characteristics were marked on a $0-100$ unstructured scale and the following traits were enrolled in the analysis: colour intensity, odour, spice odour, chewing resistance, chewing moisture, chewing fattiness, saltiness, taste of the meat dollop, spice intensity, foreign odour or taste, and preference.

\subsection{Statistical analysis}

Each product was prepared as one mixture, and one supplementation type was filled into six short casing parts (each c. $250 \mathrm{~g}$ ) according to the six different storage intervals. Repeated measurements were used for statistical comparisons between samples. One-way analysis of variance was used for all parameters, with SPSS 10 for Windows (1999) software.

\subsection{Storage and sampling}

The samples between the examinations - except the organoleptic analysis - were stored in a refrigerator at $4{ }^{\circ} \mathrm{C}$ in darkness. The samplings were performed on the $1^{\text {st }}, 6^{\text {th }}, 12^{\text {th }}, 18^{\text {th }}, 25^{\text {th }}$, and $32^{\text {nd }}$ days of storage, and each day a new stick of Párizsi $(250 \mathrm{~g})$ was sliced and analysed.

\subsection{Fatty acid profile}

\section{Results and discussion}

Raw meat and backfat contained the least n-3 FA and had the highest n-6/n-3 ratio (Table 2), but the $n-6$ content of soybean oil led to an n-6/n-3 ratio identical with that of backfat. Marked differences were found between the two vegetable oils regarding their polyunsaturated fatty acid (PUFA) content and the n-6/n-3 ratio. ALA content of flaxseed oil was higher by one order of magnitude than that of soybean oil and its n-6/n-3 ratio was the lowest (Table 2). Table 3 shows the proportional (w/w\% of FA) FA profile obtained from the graded oil substitutions. Storage-dependent alterations of the FA profile were negligible and are therefore not shown. The fatty acid profile of partially substituted Párizsi samples was diverse. The increasing amount of added oil reduced the n-6/n-3 FA ratio in all cases, mainly in the flaxseed enriched samples, whereby at $9 \%$ concentration (i.e. of the fat content) the optimal ratio of 4 (WoOD et al., 2004; TAKEUCHI et al., 2008) was approached. This product contains nearly 70 mg PUFA and 13 mg n-3 FAs/g. FAO (2008) recommends 0.25-2 g/day total n-3 FA intake, of which 1.1-1.6 g/day is the recommended daily allowance (RDA) for the precursor ALA (IOM, 2005). With the model products this can be fully reached when ingesting c. $100 \mathrm{~g}$ of the most highly substituted ( $9 \%$ flaxseed) product, which is consonant with the Hungarian national habits of Párizsi consumption. According to WooD and co-workers (2004), the optimal human fat source contains $30 \%$ proportion of saturated fatty acids and the PUFA/ saturated ratio is higher than 0.4 . In our $9 \%$ flaxseed sample this was not totally fulfilled, albeit well approached ( $40 \%$ and 0.56 , respectively), while the control sample was different from this theoretical optimum regarding the first indicator (44\%). In contrast, the control sample was appropriate in its PUFA/saturated ratio, referring to the fact that the optimally accepted FA composition in a single product is hardly attainable. Using merely vegetable 
oils, a further drawback was that desaturated and elongated FAs (docosapentaenoic and docosahexaenoic acid) were practically absent in the samples, while the cumulative RDA of these acids is $0.2 \mathrm{~g} /$ day (FAO, 2008). In future product development this can be compensated by the addition of fish oil, being, however, questionable from consumer perception aspects.

Table 3. Qualitative and quantitative fatty acid profile of the model Párizsi products

\begin{tabular}{|c|c|c|c|c|c|c|c|}
\hline \multirow[t]{2}{*}{ Fresh sample } & Control & $\begin{array}{c}3 \% \\
\text { soybean oil }\end{array}$ & $\begin{array}{c}6 \% \\
\text { soybean oil }\end{array}$ & $\begin{array}{c}9 \% \\
\text { soybean oil }\end{array}$ & $\begin{array}{c}3 \% \\
\text { flaxseed oil }\end{array}$ & $\begin{array}{c}6 \% \\
\text { flaxseed oil }\end{array}$ & $\begin{array}{c}9 \% \\
\text { flaxseed oil }\end{array}$ \\
\hline & \multicolumn{7}{|c|}{ (w/w\%) } \\
\hline C14:0 & 1.45 & 1.42 & 1.45 & 1.27 & 1.37 & 1.31 & 1.23 \\
\hline C16:0 & 26.78 & 26.22 & 25.04 & 25.14 & 25.96 & 24.93 & 24.37 \\
\hline C16:1 n-7 & 2.57 & 2.48 & 2.43 & 2.24 & 2.47 & 2.32 & 2.15 \\
\hline C18:0 & 15.65 & 15.00 & 13.87 & 14.46 & 14.59 & 14.25 & 14.46 \\
\hline C18:1 n-9 & 33.77 & 32.74 & 33.6 & 32.04 & 32.96 & 32.01 & 33.07 \\
\hline C18:2 n-6 & 14.52 & 17.32 & 18.69 & 19.57 & 16.78 & 17.00 & 17.17 \\
\hline C18:3 n-3 & 0.85 & 1.09 & 1.26 & 1.26 & 2.08 & 3.48 & 3.94 \\
\hline C20:1 n-9 & 1.08 & 0.94 & 1.00 & 0.96 & 0.95 & 0.90 & 0.96 \\
\hline C20:4 n-6 & 0.42 & 0.41 & 0.39 & 0.34 & 0.39 & 0.38 & 0.33 \\
\hline$\Sigma$ saturates & 43.88 & 42.64 & 40.36 & 40.88 & 41.92 & 40.48 & 40.07 \\
\hline$\Sigma$ MUFA & 37.42 & 36.16 & 37.03 & 35.24 & 36.38 & 35.24 & 36.18 \\
\hline$\Sigma$ PUFA & 16.91 & 19.88 & 21.38 & 22.57 & 20.37 & 21.90 & 22.42 \\
\hline PUFA/saturated & 0.39 & 0.47 & 0.53 & 0.55 & 0.49 & 0.54 & 0.56 \\
\hline$\Sigma \mathrm{n}-3$ & 1.13 & 1.35 & 1.52 & 1.49 & 2.37 & 3.85 & 4.18 \\
\hline$\Sigma \mathrm{n}-6$ & 15.79 & 18.53 & 19.86 & 21.08 & 18.00 & 19.04 & 18.24 \\
\hline$n-6 / n-3$ & 14.02 & 13.71 & 13.10 & 14.12 & 7.61 & 4.95 & 4.36 \\
\hline
\end{tabular}

nd: not detected

\subsection{Texture profile analysis (TPA)}

Texture is a major attribute of Párizsi because of its influence on the organoleptic properties. The optimal products are easy-to-slice, elastic, not too tender, having not too hard texture (Codex Alimentarius Hungaricus, 2004). These parameters depend on the raw materials, mainly the presence of animal fat (KEETON, 1994), and in our experiment the TPA parameters of Párizsi were affected by the rate of oil substitution as well as the chilled storage for 32 days (Table 4). The differences in hardness of $15 \mathrm{~mm}$ diameter cones were interpreted. Slight differences were detected between differently composed samples on the $1^{\text {st }}$ sampling day; the $9 \%$ addition of soybean oil increased the hardness of the enriched sample. The increasing flaxseed oil concentration also increased hardness - except for the 3\% flaxseed oil enrichment, which was identical with the control -, but led to much softer samples than the soybean oil. In general, a decrease in hardness would be expected when solid fat is replaced with liquid oil (Hur et al., 2008). Difference was found between the two oil types, as well. The results obtained in this study are in agreement with the work of PELSER and co-workers (2007) 
reporting that the addition of flaxseed oil to fermented sausage at $4.5 \%$ of the final product caused a softer texture. LURENA-MARTINEZ and co-workers (2004) found that the replacement of pig fat with olive oil at 5\% in liquid form caused a significant decrease in the hardness of frankfurter. The replacement of fat with extra virgin olive oil at 5-10\% decreased the hardness of fermented sausages according to Bloukas and co-workers (1997) and SEVERINI and coworkers (2003) . The added oils are liquid, whereas the backfat contains connective tissue, which may affect the structure. The oil enrichment resulted in softer texture, which was however, only statistically proven but not reported by the panel test evaluators.

Table 4. Texture profile (shear force of $15 \mathrm{~mm}$ diameter sample cones) as depending on the oil substitutions and storage time of the model products

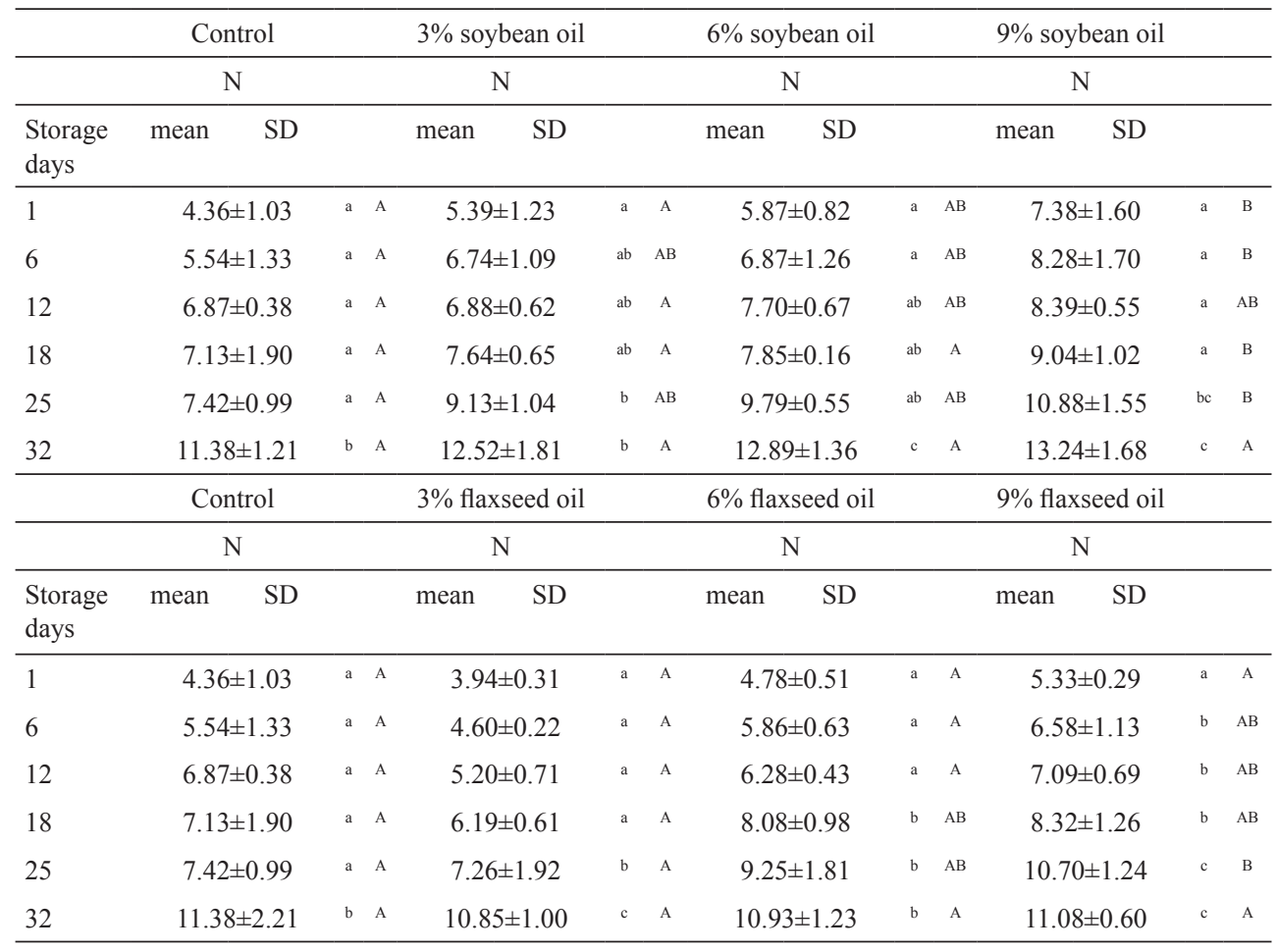

abc: significant difference $(\mathrm{P}<0.05)$ between storage days; ${ }^{\mathrm{AB}}$ : significant difference $(\mathrm{P}<0.05)$ between control and soybean or flaxseed oil added sample on each sampling day

Chilled storage caused harder samples at the end of the storage irrespective of the formulations (Table 4). Most probably the moisture content of the samples decreased and that induced higher values, but this was not directly determined in our study. The storage effect on hardness at $4{ }^{\circ} \mathrm{C}$ is in agreement with the findings of ANDRES and co-workers $(2006 ; 2009)$ and CANDOGAN and Kolsarici (2003), who also reported an increase in hardness of low fat beef frankfurters and chicken sausages. SRinivassane (2011) reported similar results, increasing hardness during storage. 


\subsection{Colour}

The other sensory quality, being an important aspect of saleability, is the colour (ANSORENA \& ATIASARÁN, 2004). Many studies reported variable results regarding the effect on colour due to the replacement of animal fat with vegetable oils in different meat products. Replacement or supplementation of animal fat with vegetable oils (PANERAS \& BloukAS, 1994; BlouKas et al., 1997; Ambrosiadis et al., 2003) in liquid form has resulted in a darker colour in meat products like frankfurters and fermented sausages. In our study, the oil enrichment also modified the colour of Párizsi samples (Table 5). Substitution with soybean oil $(9 \%)$ led to the darkest Párizsi and the highest $b^{*}$ values. The product with $3 \%$ flaxseed oil was the most similar to the control in colour parameters, and the colour difference results also confirmed this fact. BloukAs and co-workers (1997) and Muguerza and co-workers (2002) reported similar results, when the pork backfat was replaced with olive oil at $10-20 \%$ in fermented sausages. PELSER and co-workers (2007) reported different experiences, that $10-20 \%$ substitution of backfat with flaxseed oil in fermented sausages did not affect the lightness and redness, but due to the yellow colour of the flaxseed oil it resulted in higher $\mathrm{b}^{*}$ values than the control. Other methods for the enrichment of sausages, when flaxseed oil was encapsulated or in a pre-emulsified form, were not affecting the colour (CACERES et al., 2005; Pelser et al., 2007).

Table 5. CIE Lab colour of the samples at different storage days

\begin{tabular}{|c|c|c|c|c|c|c|c|}
\hline \multirow{2}{*}{$\begin{array}{l}\text { Storage } \\
\text { day }\end{array}$} & \multirow[t]{2}{*}{ Sample } & $\mathrm{L}$ & & $a^{*}$ & & $b^{*}$ & \\
\hline & & mean & & mean & & mean & \\
\hline 1 & Control & $69.8 \pm 0.63$ & a & $18.9 \pm 1.04$ & c & $7.20 \pm 1.24$ & a \\
\hline 1 & Soybean 3\% & $75.5 \pm 1.20$ & $\mathrm{c}$ & $17.2 \pm 0.27$ & ab & $7.58 \pm 0.06$ & a \\
\hline 1 & Soybean $6 \%$ & $75.6 \pm 0.76$ & $\mathrm{c}$ & $16.6 \pm 0.23$ & a & $8.17 \pm 0.13$ & ab \\
\hline 1 & Soybean $9 \%$ & $76.1 \pm 0.89$ & $\mathrm{c}$ & $16.4 \pm 0.38$ & $\mathrm{a}$ & $9.24 \pm 0.26$ & $\mathrm{~b}$ \\
\hline 1 & Flaxseed $3 \%$ & $72.4 \pm 0.15$ & ab & $18.7 \pm 0.67$ & bc & $6.81 \pm 0.07$ & a \\
\hline 1 & Flaxseed $6 \%$ & $73.8 \pm 0.91$ & $\mathrm{bc}$ & $17.1 \pm 0.60$ & ab & $7.17 \pm 0.15$ & a \\
\hline 1 & Flaxseed 9\% & $75.0 \pm 1.63$ & bc & $17.3 \pm 0.11$ & ab & $7.22 \pm 0.33$ & a \\
\hline 32 & Control & $69.1 \pm 0.95$ & a & $20.1 \pm 0.47$ & $\mathrm{c}$ & $7.93 \pm 0.18$ & a \\
\hline 32 & Soybean 3\% & $71.5 \pm 0.78$ & b & $19.0 \pm 0.57$ & $\mathrm{bc}$ & $8.67 \pm 0.22$ & $\mathrm{~b}$ \\
\hline 32 & Soybean $6 \%$ & $73.3 \pm 0.66$ & $\mathrm{bc}$ & $17.7 \pm 0.25$ & a & $9.60 \pm 0.29$ & b \\
\hline 32 & Soybean 9\% & $74.1 \pm 0.96$ & $\mathrm{c}$ & $17.6 \pm 0.27$ & a & $9.83 \pm 0.26$ & c \\
\hline 32 & Flaxseed 3\% & $71.5 \pm 0.64$ & $\mathrm{~b}$ & $19.5 \pm 0.48$ & $\mathrm{bc}$ & $8.16 \pm 0.26$ & ab \\
\hline 32 & Flaxseed $6 \%$ & $71.8 \pm 0.60$ & $\mathrm{~b}$ & $18.8 \pm 0.24$ & $\mathrm{~b}$ & $8.26 \pm 0.30$ & ab \\
\hline 32 & Flaxseed 9\% & $73.9 \pm 0.53$ & $\mathrm{c}$ & $17.4 \pm 0.38$ & a & $8.54 \pm 0.16$ & b \\
\hline
\end{tabular}

abc: significant difference $(\mathrm{P}<0.05)$ between oil enrichments on the first and the last sampling day

The effect of storage was significant on the colour parameters. At day 32, an increase was observed in yellowness (Table 5). The redness and lightness changed differently in all types. The lightness did not change in case of the control and the sample with $3 \%$ flaxseed 
oil, in the other samples the storage resulted in a decrease of lightness, most probably associated with moisture loss. Redness increased in the samples with soybean oil to the end of the storage. Similar results were found in fermented sausages prepared with olive oil or flaxseed oil by SRInivassane (2011) and Muguerza and co-workers (2002), namely that the redness and yellowness increased in samples, while the opposite was shown by ANDRES and co-workers (2009) and Papadima and Bloukas (1999). Papadima and Bloukas (1999) attributed the change of redness to the formation of nitrosylmyoglobin, which is formed by the reaction of myoglobin with nitrites, added to frankfurters as a curing agent. In our substituted samples the differences of redness value might be caused by the oxidation of nitrosylmyoglobin (SRINIVASSANE, 2011).

\subsection{Oxidation}

Neither the acid value nor the peroxide number changed markedly during the 32 days of chilled storage. Mean acid value was $0.55 \pm 0.28 \mathrm{mg} \mathrm{O}_{2} / \mathrm{kg}$ of fat content and mean peroxide value was $4.2 \pm 1.85$ meq $\mathrm{O}_{2} / \mathrm{kg}$ of fat content (handling all samples as one group). The main reason to follow possible oxidation was the elevated PUFA and the high moisture content of the model product. The lack of detectable fatty acid deterioration was most probably due to the antioxidant component of the spice mix. This condition largely contributed to the nearly constant acid and peroxide values and the practically unchanged FA profile (VALENCIA et al., 2006). It has to be added that the nitrite salt used is a potent antioxidant, while it also contributes to colour stability (ST. ANGELO, 1996).

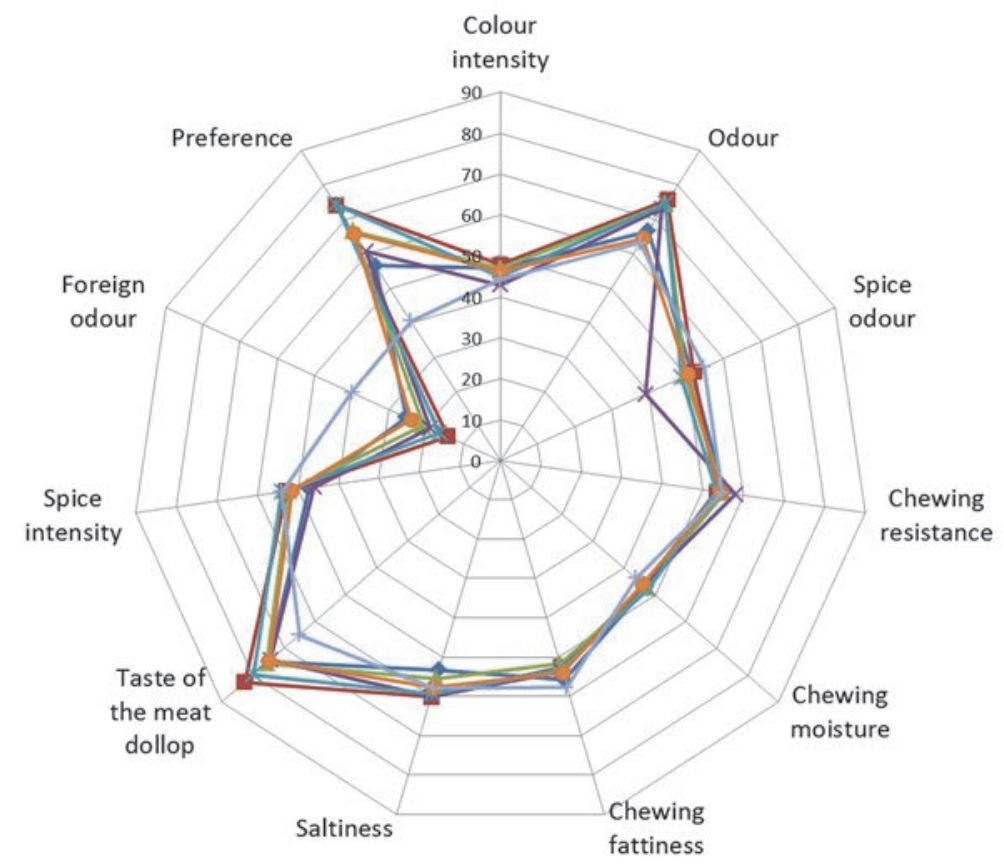

Fig. 1. Results of the sensory analysis. $\_$: Control; $\longrightarrow$ - $3 \%$ flaxseed oil; $\longrightarrow$ - $6 \%$ flaxseed oil; $\rightarrow$ : $9 \%$ flaxseed oil; $\rightarrow$ 米: $3 \%$ soybean oil; $-\longrightarrow: 6 \%$ soybean oil; $-1-: 9 \%$ soybean oil 


\subsection{Organoleptic analysis}

The most important aspect of the product improvement was not to worsen the organoleptic properties of the original product (i.e. the control) by the vegetable oil substitutions. In general, it was found that increasing vegetable oil addition decreased consumer preference (Fig. 1). Analysing all Párizsi samples, significant differences were found only in spice, foreign odour and overall preference. Lower flaxseed oil levels were more preferred considering spice odour, while with $9 \%$ oil addition the spice and foreign odour of the soybean samples were distinguished $(\mathrm{P}<0.05)$. Regarding preference, surprisingly, the $9 \%$ flaxseed oil sample was more favoured than the $9 \%$ soybean oil one, which was the least preferred sample of all. Only flaxseed oil interfered with the spice mix, soybean oil did not. This was underscored by the experience that the 3\% flaxseed oil added sample was evaluated as being spicier than the one with $9 \%$. The most similar to the control was the $3 \%$ flaxseed oil sample. MaKala (2007) and SRInIVASSANE (2011) reported similar results to the present ones, that addition of flaxseed oil to bologna pork sausage did not change sensory attributes compared to control.

\section{Conclusions}

A well-storable model Párizsi product with close to optimal and stable FA composition, fair organoleptic properties and consumer acceptance was developed with an acceptable minor drawback (lack of highly unsaturated n-3 PUFA). Further work focuses on the elimination of this disadvantage with natural additives by maintaining the advantageous storage, colour and taste characteristics.

The study was partly supported by the Bolyai Research Grant (BO/26/11/4) to A.Sz. and by TÁMOP 4.2.2/B and 4.2.2/A projects.

\section{References}

Alexander, J.W. (1998): Immunonutrition: the role of $\omega-3$ fatty acids. Nutrition, 14, 627-633.

Ambrosiadis, J., Soulatos, N., Abrahim, A. \& Bloukas, J.G. (2003): Physicochemical, microbiological and sensory attributes for the characterization of Greek traditional sausages. Meat Sci., 66, 279-287.

Andres, S., García, M., Zaritzky, N. \& Califano, A. (2006): Storage stability of low-fat chicken sausages. J. Fd Engng, 72, 311-319.

Andres, S., García, M., Zaritzky, N. \& Califano, A. (2009): Innovations in the development of healthier chicken sausages formulated with different lipid sources. Poult. Sci., 88, 1755-1764.

Ansorena, D. \& Astiasarán, I. (2004): The use of linseed oil improves nutritional quality of the lipid fraction of dry-fermented sausages. Fd Chem., 87, 69-74.

A.O.A.C. (1995): Official Methods of Analysis of AOAC International, $16^{\text {th }}$ ed. No. 965.33 Vol. 2 AOAC, Arlington, VA USA.

Bloukas, J.G., Paneras, E.D. \& Fournitzis, G. (1997): Effect of replacing pork backfat with olive oil on processing and quality characteristics of fermented sausages. Meat Sci., 45, 133-144.

Caceres, E., Garcia, M.L. \& Selegas, M.D. (2005): Design of a new cooked meat sausage enriched with calcium. Meat Sci., 73, 368-377.

Candogan, K. \& Kolsarici, N. (2003): Storage stability of low-fat beef frankfurters formulated with carrageenan or carrageenan with pectin. Meat Sci., 64, 207-214.

Christie, W.W. \& Han, X. (2010): Lipid analysis. The Oily Press Lipid Library. London, U.K. 446 pages

Codex Alimentarius Hungaricus (2004): Certain meat products. Section 1-3/13-1. 
FAO (2008): http://www.fao.org/ag/agn/nutrition/docs/Fats and Fatty Acids Summary.pdf

Folch, J.M., Leeas, M. \& Soloance-Stanley, G.H. (1957): A simple method for the isolation and purification of total lipids from animal tissues. J. Biol. Chem., 226, 495-509.

HuR, S.J., JIN, S. \& KIM, I.S. (2008): Effect of extra virgin olive oil substitution for fat on quality of pork patty. J. Sci. Fd Agric., 88, 1231-1237.

$\operatorname{IOM}$ (2005): Dietary reference intakes: macronutrients. (http://www.iom.edu/Home/Global/NewsAnnouncements/ / media/Files/Activity Files/Nutrition/DRIs/DRI_Macronutrients.ashx)

IUPAC (1987): Standard Methods for the Analysis of Oils, Fats and Derivatives. 7th ed. No. 2. 201 Determination of the acid value (A.V.) and the acidity. Blackwell Scientific Publications, Boston, MA and Oxford, UK.

Kamal-Eldin, A. \& Andersson, R. (1997): A multivariate study of the correlation between tocopherol content and fatty acid composition in vegetable oils. J. Am. Oil Chem. Soc., 74, 375-380.

KeETON, J. (1994): Low-fat meat products - technological problems with processing. Meat Sci., 36, 261-276.

Lurena-Martinez, M., Vivara-Quintana, A. \& Revilla, I. (2004): Effect of locust bean/xanthan gum addition and replacement of pork fat with olive oil on the quality characteristics of low-fat frankfurters. Meat Sci., 68, $383-389$.

MaKala, H. (2007): Effect of enriching model meat products with oils, abundant in polyunsaturated fatty acids on the selected quality parameters. Electron. J. Pol. Agric. Univ., 10, 15-23.

Muguerza, E., Fista, G., Ansorena, D., Astiasaran, D. \& Bloukas, J. (2002): Effect of fat level and partial replacement of pork backfat with olive oil on processing and quality characteristics of fermented sausages. Meat Sci., 61, 397-404.

Neuringer, M., Connor, W.E., Lin, D.S., Barstad, L. \& Luck, S. (1986): Biochemical and functional effects of prenatal and postnatal n-3 fatty acid deficiency on retina and brain in rhesus monkeys. Proc. Natl Acad. Sci., 83, 4021-4025.

Paneras, E.D. \& Bloukas, J.G. (1994): Vegetable oils replace pork backfat for low-fat frankfurters. J. Fd Sci., 59, $725-728$.

Papadima, S. \& Bloukas, J.G. (1999): Effect of fat level and storage conditions on quality characteristics of traditional Greek sausages. Meat Sci., 51, 103-113.

Pelser M.W., Linssen, J.P.H., Legger, A. \& Houben, J.H. (2007): Lipid oxidation in n-3 fatty acid enriched Dutch style fermented sausages. Meat Sci., 75, 1-11.

Riemersam, R.A. (2001): The demise of the n-6 to n-3 fatty acid ratio? A dossier. Eur. J. Lipid Sci. Technol., 103, 372-373.

Rose, D.P. \& Connolly, J.M. (1999): n-3 fatty acids as cancer chemopreventive agents. Pharm. Therap., 83, 217244.

Scheideler, S.E., Froning, G. \& Cupett, S. (1997): Studies of consumer acceptance of high n-3 fatty acid-enriched eggs. J. Appl. Poultry. Res., 6, 137-146.

Severini, C., De Pillid, T., Simopoulos, A.P. \& Baiano, A. (2003): Partial substitution of pork backfat with extravirgin olive oil in 'salami' products: effects on chemical, physical and sensorial quality. Meat Sci., 64, 323331.

Simopoulos, A.P. \& Childs, B. (Ed.) (1990): Genetic variation and nutrition. World Rev. Nutr. Diet., vol. 63, Karger, Basel.

Simopoulos, A.P. (2001): n-3 fatty acids and human health: Defining strategies for public policy. Lipids, 36, S83S89.

SRINIVASSANE, S. (2011): Development and evaluation omega-3 fatty acids enriched chicken frankfurters. $P h D$ dissertation, Dalhousie University, Halifax.

St. Angelo, A.J. (1996): Lipid oxidation in food. Crit. Rev. Fd Sci. Nutr., 36, 175-224.

Takeuchi, H., Kojima, K., Sekine, S., Murano, Y. \& Aoyama, T. (2008): Effect of dietary n-6/n-3 ratio on liver n-6/n-3 ratio and peroxisomal beta-oxidation activity in rats. J. Oleo Sci., 57, 649-657.

Valencia, I., Ansorena, D. \& Astiasara'n, I. (2006): Stability of linseed oil and antioxidants containing dry fermented sausages: A study of the lipid fraction during different storage conditions. Meat Sci., 73, $269-277$.

Wood, J.D., Richardson, R.I., Nute, G.R., Fisher, A.V., Campo, M.M., Kasapidou, E., Sheard, P.R. \& Enser, E. (2004): Effects of fatty acids on meat quality: A review. Meat Sci., 66, 21-32. 